\title{
WITH CAP REFORMS AND GATT: GREATER MARKET ACCESS FOR COCONUT PRODUCTS?
}

\author{
by \\ Aurora Alarde-Regalado ${ }^{1}$
}

The coconut industry is undeniably an important feature in the economies of the Asia-Pacific region. It is an important source of income and food. In Vanuatu, this industry contributes $41 \%$ to its total export earnings; $7.10 \%$ in the Philippines; and 8.91\% in the Solomon Islands in 1992. This industry also provides sustenance to the people of Indonesia, Malaysia, India and Sri Lanka. Coconuts are major ingredients in many food preparations in these countries.

As many coconut producing countries export their coconut-based products, they have to contend with developments in the world market. These countries would have to seriously look into the likely impact of the new oilseed regime of the European Union (EU) and the signing of the General Agreement on Tariffs and Trade (GATT) on their coconut industries. Will these new trade deals mean greater market access for coconut products?

\section{The New Oilseed Regime of the European Union}

The European Union is one of the largest producers of oils and fats. However, it is only $55-60 \%$ self-sufficient in oils and fats and animal feeds. As such, the EU is a major import of these commodities.

For example, the Philippines earned about US\$602 million from five traditional coconut products (copra, coconut oil, desiccated coconut, activated carbon and coco shell charcoal) in 1993. About $49.1 \%$ of this amount came from sales to the US and 36.2\% from the EU. From 1988 to 1993, coconut oil (crude and refined) and copra cake oil/meal comprised the bulk of the country's agricultural exports to the EU. In 1993 alone, 92\% of Philippine coconut oil cake/meal was exported to the EU. Almost 100\% of copra exports from Vanuatu were destined to the EU particularly the Netherlands. In Indonesia, 47\% of its coconut oil exports in 1992 went to the EU and 14\% to the US. Sri Lanka exported $52 \%$ of its desiccated coconut; $16 \%$ of its fresh nuts and most of its copra meal to the EU.

In November 1992, the EU reformed its Common Agricultural Policy (CAP) . The CAP, which was established amid food shortages in Europe after World War II, has the following objectives:

- to increase productivity

- to ensure a fair standard of living for the agricultural population

- $\quad$ to stabilize markets

- to guarantee regular supplies and

- to ensure reasonable prices for consumers

It was based upon three broad principles: the EC is treated as a single market for agricultural produce; EC farmers are given preference over outside suppliers, and the cost of the CAP is met by EC member governments.

\footnotetext{
${ }^{1}$ Senior Researcher, Management and Organizational Dev't for Empowerment, Inc. (MODE), Philippines.
} 
With guaranteed price support coupled with escalating levies and export subsidies, production has increased tremendously leading to huge surpluses which were dumped into the world market. These have depressed world prices of these commodities and undermined the exports of developing countries like those in the Asia - Pacific.

The budgetary costs of sustaining this kind of protection have also increased immensely. Expenditure under the Agricultural Guarantee and Guidance Fund (EAGGF) escalated from 3,928.3 million ECUs in 1973 to 23.153 .7 million ECUs in 1987. More than US\$19 billion out of the US\$48 billion annual CAP budget are spent for export subsidies alone.

With mounting pressures on the EU CAP budget and the US protest to the GATT Soya Panel that EUls policy on oilseeds impairs the US tariff concessions under Article II and III of GATT, a new oilseed policy was established. Under the new policy, the EC pays oilseed farmers a subsidy based on the area they devote the oilseed rather than on yield. Thus, the EC farmers were still assured of minimum return from growing oilseeds irregardless of yield.

The GATT panel rejected the new oilseed regime. The panel said that the new policy still distorts the market for oilseeds. In November 1992, the US and EC finally resolved their differences and agreed on a new farm deal, now known as the Blair House Accord. Under the new agreement, the EC agreed to limit its oilseed hectarage and the US dropped two protests in GATT against oilseed subsidies. The new deal also sets the base area to 5.128 million hectares for rapeseed, soybean and sunflower production. This base area would be reduced by $10 \%$ at the minimum every year. However, oilseeds and industrial use can be grown in the set-aside land. The agreement will take effect beginning in the 1995 harvest.

\section{The GATT Agreement on Agriculture}

Upon the signing of the agreement, the 117 GATT members agreed on rules and regulations to govern agricultural trade. The GATT provides for greater marxet access for agricultural commodities through the reduction of tariffs, domestic support to agriculture and export subsidies.

Under the new trade accord, tariffs will be cut by $36 \%$ over a period of six years in industrialized countries, $24 \%$ over ten years for developing countries but poorest nations will be exempted. Countries with closed markets will be required to import 3\% of their domestic needs to increase to $5 \%$ after six years.

Moreover, the value of agricultural export subsidies will be reduced by $25 \%$ over a 6 -year period while the volume of subsidized farm exports will be slashed to $21 \%$. Non-tariff barriers on farm imports will be converted to tariffs.

The EU has proposed the following tariff reduction:
Oil
Base rate \%
$\%$ Reduction
Final Rate \%

Coconut

Technical

Other

Palm Kernel

Technical

Other 
Palm

$\begin{array}{llll}\text { Technical } & 4 & 100 & - \\ \text { Food } & 6 & 36 & 3.8\end{array}$

(Source: dela Rosa, May 1994)

In the Philippines, for instance, crude coconut oil was given a 36-50\% tariff reduction by the EU and 50\% in Japan. Tariffs for industrial fatty alcohols was reduced by 54\% in the US and $37 \%$ in the EU.

The reduction on tariffs, domestic support and export subsidies might lead to greater market access. However, the question that begs to be asked is: will coconut producing countries in the Asia-Pacific region, for example, be able to maximize the new opportunities and protect themselves from adverse impacts of the opening up of their markets?

According to Kevin Watkins, Senior Policy Advisor for Oxfam that developing countries like the Philippines, Indonesia, Sri Lanka and Vanuatu should bear in mind that the "GATT and the multi-lateral trading system continue to be subordinated to the strategic interests of European and North American lobbies that are organized around big farm interests, big agricultural trading interest...." (Watkins, 1994) Brian Gardner, Director of EPA Associates, forecasted that even with the new GATT agreement, EU dumping in maintaining the main elements of their agricultural policies; there will still be heavy levels of protection' there will still be heavy levels of exports." (Gardner, 1994).

With Blair House Accord and the GATT only providing partial trade liberalization, agricultural subsidies and domestic support to agriculture were not totally eliminated. As such, the bulk of production (79\%) of oilseeds such as soybean, rapeseed and sunflower would still be highly subsidized. Moreover, since food aid is not covered by GATT, surplus production in oils and fats could still be sold in vegetable oil importing countries. In the US for example, the use of oil export programs and the Public Law 480 beginning in the late 1980s reversed the declining trend in its vegetable oil exports. The US said that the use of price subsidy programs increased vegetable oil's sales from 788,000 tons in 1991 to 1.3 million tonnes in 1992.

There is no doubt that the coconut inausLries in the Asia-Pacific region will still play significant roles in their economies. However, it should be noted that they will be playing in a rapidly changing international market arena, where they are just the bit players.

To be able to play in a highly competitive market, coconut producing countries in the AsiaPacific must address the following constraints.

\section{Stiff Competition from other Vegetable Oils and Substitutes}

Coconut producing countries should take into account that there is a rapid growth in the production of other competing vegetable oils. While coconut oil only grew slightly from 2.1 million tons in 1984 to only 2.8 million tons in 1993. From 1984 to 1993, palm oil production grew from 6.3 million tons to 13.8 million tons; rapeseed, 5.2 million tons to 9.1 million tons; soybean oil, 13.3 million tons to 17.2 million tons, and palm kernel oil, 0.8 million tons to 1.5 million tons. With these growths in competing vegetable oils, there is a relative stability of supply in other oils as against coconut oil. Producers of coconut oil should watch out for the rapid growth of palm kernel oil production (which has the same properties and applications as coconut oil). And this production is expected to grow continuously. The growth of coconut oil is not as bright because Philippine production of coconut oil is still hobbled by low productivity and production due to the senility of its trees and the continued cutting of coconut trees, among others. 
Moreover, technological advances in other vegetable oils such as the development of high lauric rapeseed oil pose a big competition to coconut oil. Calgene Inc. of California disclosed that it had bioengineered or genetically modified a canola oil which is able to make lauric acid. So far, high lauric rapeseed varieties (first generation variety has lauric/myristic acid contents of nearly 50\% while second generation varieties have $70 \%$ lauric acids) have been developed. It is claimed that these new rapeseed varieties can be grown competitively with non-genetically engineered rapeseed. Thus, it is possible to produce these varieties at prices close to canola or soybean oil. Production of first generation high-lauric rapeseed varieties in commercial quantities in the US can be done as early as 199S. Recently, Calgene Inc. got the patent rights or a stearoyl-ACP hydrolase gene from the Noble Foundation. This gene is supposedly vital in controlling the level of saturated fat stearate in vegetable oils.

Likewise, with growing tendency for low fat diets in industrialized countries, coconut oil producers should expect greater competition from new substitutes in the near future. For instance, Procter and Gamble Co. has came out with a new reduced- calorie fat cocoa butter substitutes, Caprenin, that could compete with coconut oil in the specialty fats market feeding into the confectionery and baking industries.

The prospects of coconut oil and other competing vegetable oils would also depend on the development of new products/uses of these oils. With a growing concern for the environment, many governments are now undertaking biofuels and bioenergy projects. At the EC level, the European Commission is promoting "green fuels" by extending incentives for biodiesel production. The EC intends to increase the motor vehicle market using biodiesel by 5\% the year 2005. The French are now trying to find alternative uses of rapeseed oil. The French government is urging its farmers and oil companies to process about 35,000 tons of rapeseed oil into rapeseed ester to be used as diesel fuel. ICI and the Ferruzzi Montedison subsidiary, Novamont had agreed to produce 40,000 tons per year of biodiesel from set-aside rapeseed at the ICI's Baleycourt-Verdun plant in north-east France. In the UK, John Deere Ltd., a big manufacturer of agricultural machineries, had made a biodegradable transmission and hydraulic oil from rapeseed oil which can be used in their new line of tractors and in hydraulic systems of combines and forage harvesters. The new rapeseed-based oils, Bio-Hy-Gard, is supposedly $87 \%$ biodegradable and is approved for use in the transmission and hydraulics of the new John Deere 6000 and 7000 series tractors including the earlier tractor lines. In the US, soydiesel fuel, which is being produced in 29 estates, is now used in some municipal business fleets and airport maintenance vehicles.

Coconut producing countries would have to go beyond exporting copra or crude coconut oil if they have to survive the vagaries of the international market.

\section{Major Structural Weaknesses in the Producing Countries}

The competitiveness of coconut products in the international market would be greatly improved if producing countries can address the structural constraints in their coconut industries:

(1) Low production and productivity characterized the coconut industries in the Asia-Pacific region. Coconut yield in most coconut producing countries is less than one metric ton per hectare as compared to a potential 2 to 4 tons per hectare. (see table on comparative yields)

In comparison, the yields of soybean and palm in major producing countries are quite high. In 1992/93, the world yield for soybean was 2.06 tons/hectare; 2.97 T/ha in EC-12, and 2.2 T/ha. in Brazil while world yield of palm was $3.02 \mathrm{~T} / \mathrm{ha}$. in 1992(p); $3.31 \mathrm{~T} / \mathrm{ha}$. in Malaysia and $3.44 \mathrm{~T} / \mathrm{ha}$. in Indonesia. (Oil World) 
The low coconut productivity can be attributed to several factors. These include the senility of coconut trees, climatic factors and poor cultivation practices. While there have been efforts to replace senile trees in Indonesia and the Philippines through the Small Coconut Farmers Development Program supported by the World Bank, for instance, these have not yet yielded expected results. On the other hand, the adoption of using inputs to increase yield have not been adopted yet because of the lack of funds to purchase these inputs. Many small farmers cannot afford to buy these inputs because of low returns from coconut farming.

Aside from low productivity, coconut producing countries would have to contend with high production costs. An ADB study in 1990 estimated the comparative cost of coconut oil production in Indonesia, Philippines and Sri Lanka. Production costs varied, a high US\$730/MT in public estates and US\$523/MT, smallholder in Indonesia; US\$422/MT in Southern Mindanao in the Philippines and US\$534/MT in Sri Lanka. The high cost of production in public estates in Indonesia was attributed to higher costs for fertilizers, processing and transport/marketing. In comparison, the cost of producing palm oil was lower to that of coconut oil. For instance, the cost of producing palm oil in Indonesia ranged from US\$172202/MT; US\$212-223 in Malaysia and US\$218/237 in Papua New Guinea. So with higher yields and lower costs of production, the economic rate of return in palm oil production would be higher than coconut oil production.

Major coconut producing countries like the Philippines, Indonesia and Malaysia would also have to address the inefficiencies in the domestic marketing and processing of coconut products. Copra marketing systems in these countries are controlled by cil millers through their representative copra traders in major producing areas. Copra has to pass through several hands from the farmers to the end-users. As each layer entails additional costs and profits, the costs of producing coconut oil become higher. overcapacities and obsolete technologies also characterized their oil milling/refining sectors compared to other vegetable oil producing countries making it harder for them to compete in the world market.

(4) The domestic prices of copra and coconut oil depend greatly on the international prices of coconut products. With the volatility of international prices coupled with the control of oil millers/traders on the domestic market, producers (mostly small farmers) generate low returns/incomes from coconuts. Thus, coconut farmers in Malaysia, Indonesia and the Philippines are generally poor. Most of the times, they have limited fund for additional investments on their farms.

\section{Conclusion}

The coconut industry is a vital pillar in the economies of APCC member countries. However, it faces structural problems: low yield, low-return on investment, inefficiencies in the processing and marketing of products, and highly volatile prices.

The prospects of coconut products in a relatively enlarged world market brought about by partial trade liberalization will depend on the abilities of coconut producing countries to face the challenges of a rapidly changing market. To be competitive, they must address the multitude of structural problems facing their coconut industries. The potential gains of GATT and CAP reforms on oils and fats trade will most likely go to the more efficient producers of other vegetable oils such as Malaysia, Indonesia, Argentina and Brazil, especially on the short-term. 


\section{REFERENCES}

APCC Statistical Yearbook 1992

Asian Development Bank, Industrial Crops in Asia,Agriculture Department, Staff Paper No. 7, August 1993.

Dela Rosa, Romulo, The CAP and the European Market forCoconut Oil and Copra Meal, May 1994.

Department of Agriculture, GATT and PhilippineAgriculture: A Preliminary Brief, 1994

GATT: Agreement on Agriculture (Annex 3). Document MTN/FA II-AI A-3, pp 1-25 GATT 1993a

Gardner, B. The Political Outlook for European Community Agriculture. Paper presented during the $12^{\text {th }}$ Annual European Agricultural Outlook Conference, $24^{\text {th }} \& 25^{\text {th }}$ February 1993.

The GATT Uruguay Round: Implications forExports for the Agricultural Superpowers.Briefing Paper, CIIR/SAFE Alliances, December 1993.

EU dumping to continue, " The GATT Agreement on Agriculture: will it help developing countries? A report of a CIIR Seminar held at Congress House, Great Russell St., London, 12 April 1994.

INFORM, Vol. 5 no. 4, April 1994.

Watkins, Kevin. "GATT's hidden agenda," The GATT Agreement on Agriculture: Will it help developing countries? A Report of a CIIR Seminar held at Congress House, Great Russell St., London, 12 April 1994.

Oils and Fats International, Vol. 10 No. 21994.

Pawanteh, Zurinah. Domestic Marketing of Coconut Products in Malaysia. Jakarta: APCC, November 1992.

Stevens, Christopher. Changes to the External Environment for Agricultural Development, Final Report. University of Sussex:Institute of Development Studies, June 1993.

UCAP Weekly Bulletin, various issues,1993-May 1994.12 